\title{
Manyama Braya in Banjar Angansari, Bali in Foucault's Genealogy Perspective
}

\author{
Dewa A. G. Agung ${ }^{1}$, Sanggar Kanto, ${ }^{2}$, Darsono Wisadirana ${ }^{2} \&$ I Nyoman Ruja ${ }^{2}$ \\ ${ }^{1}$ Doctoral Program of Political and Social Science Faculty, Brawijaya University, Malang, Indonesia \\ ${ }^{2}$ Lecturer of Political and Social Science Faculty, Brawijaya University, Malang, Indonesia \\ Correspondence: Dewa A. G. Agung, Doctoral Program of Political and Social Science Faculty, Brawijaya University, \\ Malang, Indonesia.
}

Received: June 13, 2017

doi:10.11114/ijsss.v5i8.2484
Accepted: July 20,2017 Available online: July 26, 2017

URL: https://doi.org/10.11114/ijsss.v5i8.2484

\begin{abstract}
Religious conflict in Indonesia has been escalated since the fall of Suharto from the presidency in 1998. However, there is still a harmonious life among different religious such as in Banjar Angansari, a small village in Bali, which inhabited by Moslem and Hindus. This phenomenon caused by their local wisdom called "manyama braya"which means "good neighborliness". Local wisdom in this research means local values that inherited by the local community which become guidelines to live together. There are lots of studies about manyama braya, nevertheless no one study about the history of this local wisdom in a particular area, such as Banjar Angansari, yet. Banjar Angansari is a traditional society that embraced Hinduism and Islam. This study aimed to explore the history of manyama braya in Banjar Angansari and its function for the harmony of society. This study is qualitative research using Foulcault's's genealogy approach. We collected the data trough deep observation in people's life in Banjar Angansari. We also collected the data from documents, such as ancient inscription, and interviewed numerous local people including the Moslems as well as the Hindus. There are several results of this study. Firstly, the manyama braya has been existed in Banjar Angansari long before they embraced Hinduism and Islam. The Sukawana Inscription ( $882 \mathrm{AD}$ ) proved that there was a harmonious live between Hindus and those who believed in Shiva Budha, long before Islam religion started to come in this region in 1982. Therefore, there's a continuity of history because Banjar Angansari's people can preserve the harmonious live between different religions up to now. Secondly, there is a discontinuity of history of Banjar Angansari. The discontinuity due to the difference of religious ideology across the time from animism and dynamism, Hinduism, and Islam. Therefore, it is hoped that this research can be seen as an attempt to reconstruct Foucault's genealogy especially about the discontinuity in history.
\end{abstract}

Keywords: Manyama Braya, continuity, discontinuity, genealogy

\section{Introduction}

After the fall of Soeharto in 1998, Indonesia starts to reform itself. This era known as "Reformasi" in Indonesia. In this era, people gain their freedom of expression. But, in the same time, many religious conflicts start to appear in various region in Indonesia such as in Ambon, Poso, Palu, etc. The religious conflicts also occur in several places worldwide. In various countries, the religious conflict can be solved trough the revitalization of local wisdom values. In Africa, the religious conflict between Islam and Christian reconciled trough the Africa Traditional Religion (ATR) (Kagema, 2015). In China, the social harmony is conducted trough Confucianism as China's value, Japan with Shintoism that guide its people to avoid conflicts (Taormina, 2014:128-129).

The religious conflict also never apper in Banjar Angansari, Bali. Even though people who lives in this village are Moslems and Hindus, they never involve in any religious conflict because they believe in "manyama braya" as their local wisdom. Manyama Braya, comes from the word "nyama" means "close relatives", and "braya" means "distant relatives", means "good neighbor", "brothers". The concept of distant relatives, especially in order to address the citizens of different religions (Mashad, 2014: 7-8). This local wisdom has a long history in this community.

Unlike the other historians, Faucoult believes that history is discontinue. The discontinuity of history of "manyama braya" reflects in various sources such as inscription or people's memory. Those sources are valuable to trace and reconstruct the history of "manyama braya" in Banjar Angansari. The historical reconstruction involves various sources, 
written or unwritten, in the dimensions of space and time (Kuntowijoyo, 2005; Carr, 2014). Written sources are written remains that provides information about the past, such as inscription, archives, or documents. Meanwhile, unwritten sources are the remains of the past that provide information related to human activities at the time i.e. monument, artifact, etc. In this study of "manyama braya" as part of Banjar Angansari history, we employ the available sources (written and unwritten) that may serves provide information both in diachronic and synchronic perspectives.

Banjar Angansari is a small village in Bali. Unlike the other village in Bali which mostly inhabited by Hindus, this village is inhabited by both Hindus and Moslems. While nationwide Moslems are majority, in Bali they are minority. In Banjar Angansari, the Hindus and Moslems live harmoniously under the Banjar system. Banjar is a traditional form of village administration in Bali which applies awig-awig (Bali's traditional law) influenced by the Hinduism values. Therefore, we choose to focus our study in this village. The history of this village along with its local wisdom has never been written before even though there is a potential to be written as an explorative research based on Faulcault genealogy.

The village history should not be underestimated, since it has an important role in shaping the history of a city and even a nation (Basundoro, 2012; Abdullah, 1987; Priyadi, 2012). The small study is important to look at the dynamics of a community in the past, as a case study that might as monitoring of the common that happened (Burger, 1990:131). The existence of a city can not be separated from the role of villages. People were living in villages before the city exist. While the villages developed into larger community i.e. city, people started to move to the city and influenced it. As Basundoro (2012:3) states that the appearance of great names, like hero, in the city can not escape from the village's history or local history. Because of that, the writing of local history or village history will provide a major contribution not only in the scientific field, but also a careful, critical and detailed historical research (Abdullah, 1987:289). According to Priyadi (2012) writing local history is challenging, so it requires other sciences i.e. sociology to help the interpretation of sources and fact from the past. For example, the concepts of interactions and transactions become essential to the writing of local history. Of course it can be done if we have the experience in doing historical research, reading published books, newspapers, as well as doing interviews with the actors and witnesses of history.

Based on the preliminary study that we conducted on the historical sites in Banjar Angansari, we found that there are only limited remains, artifact, monuments and documents. This doesn't mean the writing of Banjar Angansari village history ends or can not conducted. This explorative research about the history of "menyama braya" in Banjar Angansari could be conducted trough people's traditional historiography to uncover what was happened in the past. According to Abdullah (1985, xxi), the study of traditional historiography tries to learn the interwoven between elements of literature, imaginative work, mythology as a way of life that told by the local community. The study of myths is important as Alatas said, that the function of myth as an important element illustrated in the history and sociology (Alatas, 1988:1). Revealing the history of the people included in context of social history, which is the study of the structure and process of reciprocal actions of man as an actor, as has occurred in the socio-cultural context of the past society (Heacht, 1985:154). The result of this interaction (structure and actors) lead to historical events in the perspective of space and time.

According to some historian's view, the historical truth occurs on the pulse of the small community tucked away in its memories. Therefore, to uncover these memories, the most useful technique is interview (Hoopes, 1980; Hassan, 2004; Roosa \& Ratih, 2013). Through interviews with informants and interpretation to relevant relics, it is expected that those historical sources can provide historical information of "manyama braya" in Banjar Angansari. It is also expected that those historical sources could provide the information about the genealogy of "menyama braya" which lead to a harmonious life between Moslems and Hindus in Banjar Angansari.

We realize that writing history of a small village is not easy, especially because the lack of written historical sources that directly related to the study areas. Therefore as explorative research, the research mainly rely on interviews of informants that get "oral tradition" from their predecessors. Data gained from interview were interpreted and elaborated as well as collaborated with historical sources found to reconstruct the history of manyama braya in Banjar Angansari.

\section{Method}

This research is a qualitative study using Foucault's genealogy approach who used any form of truth that can be traced historically by an institution (Foulcault, 2002: 22). Genealogy was vague, but carefully, and was a painstaking documentary. Genealogy reconstructs all the events for a moment when they are not there, and remember the events of things that are not realized. Therefore genealogy demanded patience and detailed knowledge with extensive material resources, and serious. Therefore with genealogy would not hesitate to dig depth to allow time to provide flexibility (Foulcault, 2002: 270-271).

Foulcault stressed his rejection of the viewpoint that sees the historical process as a linear or continuous. Therefore Foulcault sees the history as a discontinuity, a disconnection. There are many factors affect the historical discontinuities, including ideological factor which is controlled by the ruler (Fansuri, 2002:8-9). By this basis, the first problem in formulating the research of manyama braya history is because of its discontinuity. Each period of manyama braya has 
its own history and record, and is not continous due to ideology, power, or lack of resources. This resulting in a period of transition (interregnum).

This study uses the historical research steps complementary with the steps of sociological research. The stages of historical research are as follows; 1) selection of topics, with consideration of emotional and intellectual closeness with the subject and the object of research, 2) heuristics, to search and collect resources (documents, monuments, oral tradition, interviews, observation), 3) criticism, both internally and externally to verify the validity of the source, 4) interpretation, that is analysis and synthesis, and, 5) historical writing (historiography), where findings will be described chronologically and continuously, and it causal effect (Kuntowijoyo, 2003; Syamhudi, 2013; Wineburg, 2006).

\section{Results}

Banjar Angansari as a community have already existed for a long time. Based on the limited sources collected in this research, it can be inferred that before Hinduism, the mutual dependence relationship based on manyama braya values might be practiced by people in this community since the prehistory, especially as part of megalithic tradition in the neolithic era. Based on the characteristics of megalithic tradition, there are various activities carried out jointly by members of the community, such as in religious activities in term of animism and dynamism, people's livelihood as part of economic activities, the production of a variety of live equipments as cultural artifacts, living together in a society as part of social activities, and the political activities in term of the leader's choosing based on primus inter pares value.

It can be inferred that at the time, they were already aware of the need to live together, the need for assistance from other humans resulting interdependence of life like human beings as social creatures. As Marwati Djoned Poesponegoro and Notosusanto (2010:112) states that various religious activities, economic, socio-cultural, as well as in the political field has been done as a tradition in this time. Therefore, the megalithic tradition is a social, economic, cultural, religious, and even politics phenomenon. In turn, it mixed and overlapping to form a local variations and then mixed with elements of Hindu culture, and Islam (Jati, 2016: 12-13).

Based on our observations, there was a megalithic tradition in Banjar Angansari. This can be seen in the utilization of the stone relics as a place of worship, particularly as a shrine in temple. The stone relics built in megalithic era that can be found in Banjar Angansari are pelinggih. Pelinggih are buildings made with molded in such a way that serves as a place of worship for Hindus to worship Almighty (Read: Sang Hyang Widhi Wasa). Pelinggih can be found in places of worship of Hindus in Bali, both in the private temple (mrajan), or a village temple (Tri Khayangan), or in sad khyangan temples. According to Haine Geldern (1945:129-167) pelinggih is part of old megalithic tradition which constructed from large stones. Taking into account the local environmental conditions, it is possible that this area is part of the megalithic site. Moreover, this area is part of Trunyan which famous by its megalithic burial system.

In addition, the megalithic tradition that is practiced by the Banjar Angarsari's people in term of their belief to the sacred power of keris (an asymmetrical traditional dagger with distinctive blade-patterning achieved through alternating laminations of iron and nickelous iron). Those belief to the sacred keris is part of dynamism practice which could be traced back to the religious belief in the prehistory era. The sacred kreris is stored in Pura Bale Agung. The villagers believes that sacred keris keep this village from all dangers (mala bahaya). The villagers belief that keris always extends over time so that the sheath must always be adjusted to the length of the keris. Mr. AP, the Kelian Banjar Adat, said:

"......Here we believe there is a sacred keris that must be stored and cleaned in every ceremony (odalan). The Keris is a heritage that is not known how centuries its age. The Keris is keeping this area from danger (mala), oddly enough, the keris size is always getting longer, firstly we are not experiencing difficulties to removed keris from the sheath, but now it must be tilt first to get out, I think this keris is living....."

Those keris is stored in pelinggih. Up to now, all villagers, both Hindus and Islam, belief that the keris and pelinggih have supernatural power. They share a common belief about the sacred keris and pelinggih. Those belief is also actualized in various form of their daily life. They preserve those relics together. They also hold ceremonies to honor the relics together. They de vide the work for the ceremonies so that every villagers could participate. Those activities and beliefs are part of the realization of manyama braya.

Under these conditions, mutual cooperation is the basis of their communication in social relations. The good cooperation on the basis of mutual interest occur in this society. They also believe that public interests are above all of the individual interest. All of that happened through sincere communication and is led by a chief or a leader who adhered together honestly. Typically, the position as a leader is held by the oldest authoritative. His position in society is very important, it is a figure that is respected and honored. The tradition of honoring parents who have the role of the leader, and then de veloped further into a kind of cult that later pioneered the birth of religious conception manifested in the megalithic buildings (Poesponogoro \& Notosusanto, 2010:245). 
During the influence of Hinduism, menyama braya as local wisdom persists as a guide for social interaction which can be inferred from Sukawana inscription 804 Saka (882 AD). The inscription is the oldest inscriptions in Bali until today. This inscription mention several villages, such as Sukawana, Trunyan, Gobleg, and the name of the region "Angsari" as hermitage for several hermits or monks from various religions or sects including Buddha, Siwakangcita, Siwanirmala, and Siwapradnya. This inscription serves as a clue that the manyama braya in Banjar Angansari continues in the $9^{\text {th }}$ century.

Sukawana village is the old village or villages Bali Mula whose inhabitants are descendants of Bali Aga. Sukawana means "love in the forest". Because supposedly Sukawana people used to live in the woods. One of the banjar in the village Sukawana named Kutadalem, which etymologically means kuta means "city" and the dalem means "palace". So Kutadalem is believed to be the capital of the Kingdom of Bali Dwipa (Putra, 2012). So, the Banjar Angansari possibly is an ancient village that has been named by inscriptions Sukawana the year $882 \mathrm{AD}$, and in the subsequent development of the migrants come from other areas on the island of Bali. Based on the above, and information from several informants, it could be inferred that the residents of Banjar Angansari generally are immigrants, which came from the city of Bangli, Tabanan, Klungkung, Karangasem, Buleleng and so are known as Bali Majapahit. This proves that before the settlers came, in this region (see: Banjar Angansari) existing native of Bali, known as Bali Aga or Bali Mula.

The Bali Aga was differ with the immigrants or Bali Majapahit. Their differences are including the caste system and the burial system. However, with these differences, especially in general they are immigrants with different cultures and customs there has been no conflict among them. This proves that the differences in beliefs, religious practices, and culture of the people in Banjar Angansarisince was never became a problem. Of course this is due to their sense of brotherhood, good neighborliness known as menyama braya.

In the history of ancient Bali there was a conflict between Hindus from various schools that exist at the time. In the view of Goris's, in Bali at first there were 9 (nine) sect, namely; Shiva sect Sidhanta, Pasupata, Bhairawa, Wesnawa, Boddha or Sogatha, Brahmin, Sage, Sora and Ganapatya sect. Through political policy by Mpu Kuturan, all these sects can be united with the construction Tiga Khayangan and the desa adat in the 11th century. So far the Hindus in Bali can live harmoniously and in any indigenous desa adat or banjar should have temple of khayangan tiga as unifier. According Goris (1974:10-27), the ninth stretcher sect has its own characteristics such, like Shiva Siddanta, Shiva position in the religious importance sect. This sect is dominant compared to other sects. Pasupata, this sect would like to repeat the confidence in Hisdustan, who believe as a follower of Shiva, as the cult of the phallus (lingga) as the hallmark of this sect. Bhairawa sect, the sect including Durga sect and are already impressed their syncretism with Buddhism, because there is also the name Bhairawa Buddhism. Waesnawa sect, followers of this sect as Vishnu, who is one of the Tri Murti, although this sect is not so popular. In Indonesia, this sect adheres kingdom is the kingdom Tarumanagara in West Java who believe in the soles of the feet of Lord Vishnu in Ciaruteum inscription dating from the 6th century. Boddha-Sogata are groups of pastors in Bali officially recognized until now, they are the pedanda Buddha. Brahma sect, the sect is a group that still maintains trasdisi or custom, as opposed to sectarian groups. Sect of Rsi, this sect is also a group of the Rsi who came from Java, they are the hermits, monks, and the wise and holy. In Bali a $r s i$ is pedanda or those who act as religious leaders, but does not come from the Brahmin caste. Sora sect, the sect puts the cult of the god Surya or the Sun God foremost. And sect devotee of Ganesha, the sect is nature itself, now it is not left at all in Bali.

Manyama Braya life is not only a fellow Hindu, with a variety of religions, but also with the religion of Buddhism. This can also be proved by the contents of the Sukawana inscription that mentions the name Cintamani as bhiksu hermitage, Shivakangcita, Shivanirmala, Shivapradnya (at Banjar Angansari there is a family of Buddhist sects Keling). According Ardana (Ardana, 1982, p. 21), here is unclear religion professed by the three characters, given the use of the word bhiksu (Buddhist) and the name of Shiva (Hindu). Perhaps the two religions has been going syncretism become Shiva-Buddha because at the time of King Udayana originating from the 10th century, Shiva-Buddha religion have been used as a state religion..

He mentioned the name of bhiksu, siwakangcita, siwanirmala, siwapradnya, reminiscent of the names of religious leaders, both Hindu and Buddhist. Bhiksu is the name of Buddhist leaders and Shiva reminds one of the streams in Hinduism and one of the gods worshiped is Lord Shiva in the concept of Tri Murti (Brahma, Vishnu, and Shiva). This inscription clearly inform their harmonious interaction between Hinduism and Buddhism that is based on local wisdom manyama braya. Hinduism and Buddhism based on the historical background of Indian origin are estimated to arrive in Indonesia in the early $\mathrm{AD}$. In his native land (read: India) the emergence of Buddhism is a protest against Hinduism. Buddhism opposed the belief in the Gods, as well as the caste system in society. Even in Hinduism also internal conflicts, because in general Hindus in India have a philosophy of life "people can not be a Hindu, but was born into a Hindu". This means that not everyone can be a Hindu if not born to parents who are Hindus. The condition is not the 
case in Indonesia, as evidenced by the rise of religious kingdoms Siwa-Buddha. It turned out that this can be done by moderate Hindu sect called Shiva Sidhanta, which allow non-Hindus to Hinduism through wratyastoma ceremony.

Considering the harmony that is based on local wisdom of manyama braya in Banjar Angansari among religious followers turned out to have been carried out, handed down by his ancestors in Java. This, at least can be started from the Hindu-Buddhist kingdom in Central Java. In Central Java until now believed to have once stood the royal Hindu and Buddhist living in the same time. Parallelism of religion occurred in their lives, this is demonstrated by their relics (Read: candi), both Buddhist and Hindu temples. Even based on the analysis Casparis's based inscriptions left behind that in the middle of the 9th century occurred a marriage between Rakay Pikatan from Hindus with Pramodawardani is Buddhist (Poesponogoro \& Notosusanto, 2010: 153-154). Harmony between Hindus and Buddhists are still happening, even more happening syncretism the kingdoms in East Java. This can be evidenced by the emergence Wangsa Isana under Mpu Sindok. Based on the book of Sanghyang Kamahayanikam, that Mpu Sindok are followers of Religion Shiva-Budda.

At the beginning of the book mentioned sentence Om Nama Buddhaya, and the other side is written siwaistis. This proves harmonious relations between Hindu and Buddha has happened before. Likewise, the post-dynasty kings Isana are the kingdom of Singosari and Majapahit where more and more convergence between the Hindu and Buddhist occurred since its kings were buried as Shiva and Buddha. As Kertanegara king of Singhasari and Majapahit king of Raden Wijaya as buried as Shiva and Buddha.

Hindu kingdoms in Bali are the continuation of the Hindu kingdoms in Java, so that a harmonious interaction still remains, especially with the local wisdom manyama braya. There are archaeological remains that until now we can see, that there is a temple as a place of worship of Hindus are Hindu-Buddhist heritage, the Pura Goa Gajah. Inside the temple there are relics Yoni as a manifestation of Tri Murti for adherents of Hinduism. There is also a stupa and Tara by local people named Men Brayut's is a relic of Buddhism. Morepover, in Pura Kebo Edan, a relic of Buddhism Bhairawa until now serves as a place of worship Hindu temple. On this basis, based on the inscription Sukawana are mentioned Cintamani, name "Angsari" (maybe origin of the name Angansari) as the hermitage of bhiksu, siwakangcita, siwanirmala, siwapradnya proved already occurred harmonious interaction between the Hindu and Buddhist and the local community which still adheres animism and dynamism. Moreover, until now in Banjar Angansari are also members of the community of Buddhist sects Keling.

Since 1982, there are members of the community in Banjar Angansari who previously embraced Hinduism to Islam. This kind of religious conversion process is not easy because it was accompanied by a variety of consequences, until now. Whatever the reason, transfer my self to faith with a previously regarded as infringing on the values of their religion to sanction the bad, to the sanctions go to hell. So that applies not only sanctioned religion, but also social sanctions, especially those from the majority group (read: Hindu). As stated by Mr. SD :

“....In 1982 I was with some of my brothers converted to Islam, we serve Islam by Habib Adnan. At that time many relatives and people here do not accept it if we convert to Islam. The reaction of families and communities at the time, initially had been a bit of tension, misunderstanding because we entered Islam. Places of worship such objection shall we leave. Besides, because the conversion to Islam of course we forgo the ritual beforehand. Especially as the elections in 1982. It can we tolerate, but gradually understood until now we live in harmony...."

Mr. SD statement was reinforced by Mr SL information, said:

"....furthermore father decided to convert to Islam followed by 3 brothers, while 4 other siblings remain a Hindu, and since then the disease is healed. After converting to Islam Abdul Ibrahim's father's name change. This happened less than 1982's. Because it will be the election year, the issue of transfer of this religion became crowded. Family father despised many people, including his own family. Finally, to relieve the situation, Chairman of the MUI Bali KH. HA joint forces dropped straight to Kutuh...."

So is the statement of Mr. KA;

“....at first conversion as an issue among their families, but can be solved by mutual understanding, so among the brothers there were Hindu and Islam until now...."

This informant important recognition of our analysis, particularly related to time of arrival of Islam in 1982, before the

\footnotetext{
${ }^{1}$ According to Mr. Haji Sunardi daily board MUI Bangli district, confirmed that an important person as a witness at that time that there are members of the public who wish to convert to Islam in Banjar Angansari is Habib Adnan. He currently is Chairman of the MUI Bali, which need to be explained, that he was "not" Islamize, but the only witness for the citizens who want to return to the ir ancestral religion, namely Islam
} 
implementation of the third election. Election is a political event, and it was a political effort to achieve the goals that are sometimes used in various ways from good to bad. Interests speak, so there is the view that "politics was beautiful, but dirty, smooth like cotton, rough like a tiger are starving slippery like an eel, if you win and become a hero, and if he lost to waste". Precisely for fear of being junk politics if he lost, then the tendency will use various means to obtain victory to become a hero.As said by Niccolo Machiavelli and Thomas Hobbes in Leviathan (1651) which defines politics is the sheer power (kekuasaan), that "politics is power". Supposedly as stated by Ibn Khaldun, that politics is the extent of mankind as the highest and noblest. Because of the political life must be faced with the best aspects of human beings, namely in terms of morality and religion (Hidajat, 2002: 4-5). So is reinforced by Moh. Natsir that Islam does not recognize the separation between religion and politics (Noer, 1987: 126-127). According to this interpretation means that the political researchers must be inspired by the values of Islam so that an ethical politics in accordance with the guidance of Islamic values and does not justify all means to achieve the goal.

This condition, psychologically can feel how the pressure faced by the new Muslims and the minority against the majority Hindus. However, as information from the above said, "this can we tolerate and gradually understood until now we live in harmony". This means that although transfer my religion to Islam and the time of the political events that election, but did not lead to open conflict. Of course this is caused by local wisdom manyama braya like they've inherited from their ancestors. According to WW as one of the Muslim leaders who later named AI said;

"....we are here in harmony, let alone our common ancestor, so there is no conflict, we all have family ties here, only then there are Hindus and Muslims. My wife is a Hindu and still keep a good relationship with the brother of Gung Putra who is now a Klian Banjar Adat...."

Researchers also confirm the statement from Mr. WW to AP to know the truth of the information given. He said;

"....coincided with the emergence of Banjar, the term "behave Braya" already known. Since I live here (read: Banjar Angansari) has been implanted live in harmony with everyone, including with my brothers who are Muslims. Among us, although different religions, but still has a family relationship. As Mr. Mustakim (Islam) is my cousin because her brothers with my mother. Even Jro Bandeso is mindon (second cousin) from Mr. Mustakim. Because of that religious differences do not become a hindrance to our mutual respect...."

Based on KA:

"......conversions among the people Kutuh now is not exceptional. People used to convert for a wedding can be a major problem in the family, but now because of the changing times it is not a problem. Each parent would not mind anymore, because what is important both love each other. People who want to convert is usually a release of religious ceremonies....."

Based on this information, the researcher wants to prove with the request that he (Mr WW) for the origin of his family recounted the sharing. He began his story by mentioning the names of the first to enter Islam. The story came from, the researchers tried to reconstruct the genealogy of that. Researchers can give an idea that because marriage makes new family. They have a blood relationship, so that they can unite. With time, some of them do go in Islam (1982) and there are still Hindus until now, that is the one factor that causes them to live in harmony which is based on local wisdom by his ancestor named manyama braya.

Based on personal interview with Mr. WW (Abdul Ibrahim) who explained his family, at first there are seven people were the first to convert to Islam. They are; 1) Wayan Rasun after becoming Muslim changed its name to Rasun, 2) Nyoman Gelis, then became Sariman, 3) Wayan Raspa, becoming Ikhsan, 4) Nengah Sumantra be Syahmin, 5) Nengah Gabig, be Awaluddin, 6) Made Trima, memjadi Abdul Karim, and 7) Nengah Maat, after becoming a Muslim called Maat. Wayan Rasun (Rasun) married local women Hindus who later converted to Islam. From the results of the marriage gave birth to five children in quick succession; 1) Wayan Warsa, who later became a Muslim named Abdul Ibrahim, 2) Musdhukur (Muslims), 3) Rasik Mangku (Hindu), 4) Nyoman Tulio (Hindu), and 5) Abdul Karim (Islam). Wayan Warsa, married a local woman named Wayan Hindu Sri, which at that time they were both Hindu. In 1982 they converted to Islam so Wayan Warsa changed its name to Abdul Ibrahim, and Wayan Sri Berbah name to Saparni. From this marriage has four children, namely; 1) I Wayan Ranji (Sodikin), 2) Mustakim, 3) Rahmawati, and 4) Moh. Ali Gofar. Interesting story of Wayan Warsa (Abdul Ibrahim), that is currently the number one son was born, they were Hindus and in accordance with the prevailing culture as Hindus, they also carry out a ritual like otonan at the age of six months. As like other Hindus, they also carry out the ceremony with the cook "pigs". But since his son's number two until the fourth no longer carry out the ceremony because they were born Muslim.

\section{Conclusion}

In genealogy, people in Banjar Angansari have the same historical background. Based on the findings of researchers, that the local community social relations since the tradition started megaliitik. Megalithic tradition, when viewed 
substantially still known until now, such as a variety of household appliances made of stone, even religiously still practice their belief in the objects (read: stone) which is considered to have supernatural powers in Banjar Angansari. Based Sukawana inscription from the year 804 Saka (882 AD), arguably the oldest inscriptions in Bali until today. This inscription, in addition to naming Sukawana, also names other villages, such as; Trunyan year 833 Saka (911 AD), Gobleg year 836 Saka (914 AD), and the name of the region "Angsari" possible Angansari now. That's when Hindu and Buddhist influence began to be known to the local community.

Since 1982, Banjar Angansari carve their own history, because when it started the community members who are Muslims. Ideologically certainly different, earlier if all members of society are Hindus, but since 1982 has occurred polarization between Hindus and Muslims, yet they are still living in harmony. This means that long ago, that since the people in this village has lasted a harmonious life that is based on the value of local wisdom manyama braya.

\section{References}

Abdullah, T. (1985). Ilmu Sejarah dan Historiografi, Arah dan Perspektif. Jakarta: Gramedia.

Abdullah, T. (1987). Dari Sejarah Lokal ke Kesadaran Nasional: Beberapa Problem Metodologis. Dalam T. I. Alfian, Dari babad dan Hikayat Sampai Sejarah Kritis (hal. 239). Yogyakarta: UGM Press.

Alatas, S. (1988). Mitos Pribumi Malas, Citra Orang Jawa, Melayu dan Filipina Dalam Kapitalisme Kolonial. Jakarta: LP3ES.

Basundoro, P. (2012). Pengantar Sejarah Kota. Yogyakarta: Penerbit Ombak.

Burger, D. (1990). Desa Ngablak (Kabupaten Pati) Dalam Tahun 1869 dan 1029. Dalam T. Abdullah, Sejarah Lokal di Indonesia (hal. 131). Jakarta: LIPI.

Carr, E. (2014). Apa itu Sejarah. Depok: Komunitas Bambu.

Fansuri, H. (2002). Sosiologi Indonesia Diskursus Kekuasaan dan Reproduksi Pengetahuan. Jakarta: LP3ES.

Foulcault, M. (2002). Pengetahuan dan Metode Karya-Karya Penting Foucault. Yogyakarta: Jalasutra.

Gelderen, H. (1945). Prehistoric Research in Nedelands Indies. Science and Scientist in The Netherland Indies, 129-167.

Heacht, J. (1985). Sejarah Masyarakat. Dalam T. Abdullah, Ilmu Sejarah dan Historiografi, Arah dan Persepektif (hal. 154). Jakarta: Gramdedia.

Hidajat, I. (2002). Teori-Teori Politik. Yogyakarta: Pustaka Pelajar.

Jati, S. S. (2016). Situs-Situs Megalitik di Malang Raya. Malang: UM Press.

Kagema, D. N. (2015). The Role of the African Traditional Religion in the Promotion of Justice, Reconciliation, and Peace in Africa in the Twenty-first Century: A Kenyan Experience. International Journal of African and Asian Studies.

Kuntowijoyo. (2005). Pengantar Ilmu Sejarah. Yogyakarta: Bentang Pustaka.

Mashad, D. (2014). Muslim Bali. Jakarta: Pustaka Al-Kautsar.

Noer, D. (1987). Partai Islam di pentas Nasional. Jakarta: Grafitipers.

Poesponogoro, M. D., \& Notosusanto, N. (2010). Sejarah Nasional Indonesia II. Jakarta: Balai Pustaka.

Priyadi, S. (2012). Sejarah Lokal, Konsep, Metode, dan Tantangan. Yogyakarta: Penerbit Ombak.

Syamhudi, M. H. (2013). Satu Atap Beda Agama. Yogyakarta: PT. Pustaka Ilmu Group.

Taormina, R. J. (2014). Social Harmony in Decision Making: Costs and Benefits in Chinese Society. Open Journal of Social Sciences.

Wineburg, S. (2006). Berpikir Historis. Jakarta: Yayasan Obor Indonesia.

\section{Copyrights}

Copyright for this article is retained by the author(s), with first publication rights granted to the journal.

This is an open-access article distributed under the terms and conditions of the Creative Commons Attribution license which permits unrestricted use, distribution, and reproduction in any medium, provided the original work is properly cited. 